\title{
PENGARUH HARGA, CITRA MEREK, DAN KREDIBILITAS PERUSAHAAN TERHADAP NIAT MEMBELI KONSUMEN PADA PRODUK KAWASAKI DI KOTA YOGYAKARTA
}

\author{
THE INFLUENCE OF PRICE, BRAND IMAGE, AND CORPORATE \\ CREDIBILITY ON CONSUMER'S PURCHASE INTENTIOSN ON KAWASAKI \\ PRODUCT IN YOGYAKARTA CITY
}

\author{
Pamuji Hari Santoso \\ Sekolah Tinggi Ilmu Ekonomi Pelita Indonesia \\ pamuji.hs20@gmail.com
}

\begin{abstract}
The low sales of Kawasaki motorcycles in comparison with its competitors leads to further analysis of the factors that influence it. This study aims to determine the effect of price, brand image, and the credibility of the company to purchase intentions. The population in this study is the entire population or people who live in the region of Yogyakarta. Convenience sampling is the researcher's choice in sampling. For data collection, the authors disseminate 250 questionnaires to the respondents, but only 217 data is feasible to use. The analytical tool used is the test of validity and reliability, multiple regression, classical assumptions and double determination. The results show that there is influence of price, brand image and credibility of the company towards consumer's purchase intention on Kawasaki products in Yogyakarta city.

Keywords: Price, Brand Image, Corporate Credibility, and Intention to Buy
\end{abstract}

\begin{abstract}
ABSTRAK
Penjualan sepeda motor Kawasaki yang rendah di banding dengan pesaingnya menyebabkan perlu adanya analisis lebih lanjut terkait faktor yang mempengaruhinya. Penelitian ini bertujuan untuk mengetahui pengaruh harga, citra merek, dan kredibilitas perusahaan terhadap niat membeli. Populasi dalam penelitian ini merupakan seluruh penduduk atau masyarakat yang bertempat tinggal di kawasan Daerah Istimewa Yogyakarta. Convenience sampling menjadi pilihan peneliti dalam pengambilan sampelnya, Untuk pengumpulan data, penulis menyebarkan 250 kuesioner kepada responden, tetapi hanya 217 data yang layak untuk digunakan. Alat analisis yang digunakan yaitu uji validitas dan realibilitas, regresi berganda, asumsi klasik dan determinasi ganda. Hasil penelitian menunjukkan bahwa terdapat pengaruh harga, citra merek dan kredibilitas perusahaan terhadap niat membeli konsumen pada produk Kawasaki di kota Yogyakarta.
\end{abstract}

Kata kunci : Harga, Citra Merek, Kredibiltas Perusahaan, dan Niat Membeli. 


\section{PENDAHULUAN}

Perkembangan pasar otomotif di Indonesia pada akhir - akhir ini semakin meningkat, khususnya untuk kendaraan roda dua. Perkembangan teknologi yang semakin pesat, menyebabkan semakin banyak jenis kendaraan roda dua yang ditawarkan di pasaran guna memenuhi kebutuhan masyarakat. PT Kawasaki Motor Indonesia (KMI) sebagai salah satu perusahaan asal Jepang yang bergerak di bidang otomotif dan merek yang cukup terkenal dalam pangsa pasar otomotif di Indonesia sudah menyadari kebutuhan masyarakat akan kendaraan roda dua. Akan tetapi ada beberapa perusahaan sejenis yang menjadi pesaing bagi Kawasaki, misalnya saja Honda, Suzuki, Yamaha, dan lainnya. Kawasaki sendiri sampai saat ini menempati posisi keempat dalam pasar otomotif Indonesia, khususnya kendaraan roda dua. Hal ini dapat dilihat pada tabel berikut :

Tabel 1 Penjualan sepeda motor pada 2009 anggota AISI berdasarkan merek dan kategori

\begin{tabular}{|l|l|}
\hline Merek & Total \\
\hline Honda & 2.704 .097 \\
\hline Yamaha & 2.674 .892 \\
\hline Suzuki & 438.158 \\
\hline Kawasaki & 61.217 \\
\hline Kanzen & 3.143 \\
\hline
\end{tabular}

Sumber : ZBJ - kompas.com

Dari tabel diatas, penjualan motor Kawasaki mencapai 61.217 unit secara keseluruhan untuk tahun 2009. Untuk motor sport, penjualan motor Kawasaki mencapai 45.030 unit pada tahun 2009 . Hal ini menunjukkan penjualan dan pangsa pasar motor Kawasaki di Indonesia masih rendah dibandingkan dengan merek - merek pesaingnya.
Harga merupakan satu faktor penting dari suatu produk yang dapat menarik niat membeli konsumen. Scitovszky dalam Dodds et al (1991) mengamati bahwa penggunaan harga sebagai indikator kualitas produk tidak rasional, tetapi harga merupakan suatu kepercayaan di dalam pasar yang ditentukan oleh interaksi dari kekuatan kompetitif terhadap penawaran dan permintaan. Harga suatu produk akan memiliki peranan terhadap urutan "natural"dari persaingan produk, sehingga menghasilkan kekuatan hubungan yang positif dengan kualitas produk.

Merek adalah suatu nama, simbol, tanda, desain atau kombinasi diantaranya, dan ditujukan untuk mengidentifikasi barang atau jasa dari seorang penjual atau kelompok penjual dan untuk membedakannya dari para pesaingnya (Kotler, 2003). Dalam dinamika pasar yang sangat kompetitif, merek mempunyai peran yang sangat penting sebagai pembeda. Merek disini terkait dengan citra merek yang tertanam dalam benak konsumen, sehingga tidak akan mudah ditiru oleh pihak lain. Merek merupakan suatu ekspresi yang akan menjadi simbol yang unik yang nantinya akan berada dalam pikiran dan hati konsumen.

Kredibilitas perusahaan adalah sejauh mana perusahaan dipandang memiliki keahlian dan dipercaya (Mowen dan Minor, 2001). Sedangkan menurut Menurut Lafferty et al (2002), kredibilitas perusahaan merupakan bagian dari citra perusahaan yang ditimbulkan dari kesan baik yang berasal dari pikiran konsumen. Kredibilitas perusahaan dapat dibentuk melalui bantuan dari media massa, dimana nantinya informasi dari perusahan dapat tersampaikan kepada konsumen. 
Penelitian ini terinspirasi oleh rendahnya penjualan dan pangsa pasar yang diperoleh oleh Kawasaki yang dipengaruhi oleh niat membeli konsumen. Tujuan dilakukannya penelitian ini adalah untuk menganalisis mengenai harga, citra merek, dan kredibilitas perusahaan apakah mempunyai pengaruh yang signifikan dan positif dengan niat membeli (intention to buy) seseorang, yang sebelumnya akan mengarahkan seseorang untuk mencari-cari informasi akan suatu produk yang sesuai dengan kebutuhan, dengan berdasar motivasi untuk memperoleh keinginan yang dianggap dapat memuaskan dirinya.

\section{Produk}

Kebutuhan, keinginan dan permintaan manusia mendorong perusahaan agar menciptakan produkproduk yang mampu memberikan mereka kepuasan. Menurut Kotler dan Amstrong (1996:274), produk adalah segala sesuatu yang ditawarkan ke pasar untuk mendapatkan perhatian, dibeli, dipergunakan dan yang dapat memuaskan keinginan atau kebutuhan konsumen.

Produk terdiri dari 3 tingkatan yaitu sebagai berikut :

a) produk inti ( core product ) yaitu tingkat yang paling mendasar sekali, apa yang sebetulnya ingin dibeli oleh konsumen;

b) produk aktuil, disebut juga produk formal yang tangible dengan 5 karakteristik : ciri - ciri ( features ), gaya ( style), nama ( brand name), kualitas ( quality), dan kemasan ( packaging );

c) produk tambahan ( augmented product ) merupakan suatu paket yang ditawarkan oleh produk - produk tertentu misalnya pemasangan dan garansi.

\section{Perilaku konsumen}

Perilaku konsumen merupakan suatu tindakan yang langsung terlibat dalam

mendapatkan, mengkonsumsi, dan menghabiskan produk atau jasa, termasuk proses keputusan yang mendahului tindakan ini. Perilaku konsumen dipengaruhi oleh apa yang dipikirkan (kognisi) dan di rasakan (pengaruh), apa yang mereka lakukan (perilaku), dan apa serta dimana (kejadian di

sekitar) yang mempengaruhi serta dipengaruhi oleh apa yang dipikirkan, dirasa, dan dilakukan konsumen. Menurut Nugroho (2003:3), perilaku konsumen adalah interaksi dinamis antara afeksi dan kognisi, perilaku, dan lingkungannya dimana manusia melakukan kegiatan pertukaran dalam hidup mereka.

Dalam proses pengambilan keputusan yang rumit sering melibatkan beberapa keputusan, suatu keputusan (decision) melibatkan pilihan di antara dua atau lebih alternative tindakan (atau perilaku). Keputusan selalu mensyaratkan pilihan di antara beberapa perilaku yang berbeda. Untuk pengambilan keputusan, semua aspek pengaruh dan kognisi dilibatkan dalam pengambilan keputusan konsumen, termasuk pengetahuan, arti, kepercayaan yang diaktifkan dari ingatan serta proses perhatian dan pemahaman yang terlibat dalam penerjemahan informasi baru di lingkungan.

\section{Harga}

Harga adalah nilai tukar suatu produk atau jasa. Harga adalah jumlah yang seorang pembeli bersedia membeli untuk suatu barang atau jasa dan merupakan nilai yang diminta seorang penjual untuk barang yang ditawarkan untuk dijual (Kotler, 2003). Harga adalah faktor utama dalam bersaing untuk penjualan barang industri maupun barang 
konsumsi. Ada 3 pendekatan pokok dalam penetapan harga, yaitu:

a) Orientasi pada biaya.

Tidak mungkin diperoleh laba sebelum perusahaan dapat menutup biaya-biayanya. Oleh karena itu, kebanyakanperusahaan

menggunakan jenis tertentu pendekatan biaya dalam penetapan harga, 3 jenis terpenting adalah pendekatan biaya plus, target dan analisis piutang pokok.

b) Pendekatan yang berorientasi pada persaingan.

Pada pasar-pasar ini, perusahaan menetapkan harga produknya dalam hubungan dengan harga produkproduk pesaing. Harga mungkin ditetapkan untuk dapat bersaing atau mungkin ditetapkan diatas atau dibawah harga pesaing.

c) Penetapan harga yang berorientasi pada permintaan.

Pada pendekatan ini penetapan didasarkan atas perkiraan besarnya penerimaan dari hasil penjualan dengan harga yang berbeda-beda. Kalau perkiraan-perkiraan ini

sudah lengkap jumlahnya dibandingkan dengan biaya dengan harga yang berbeda-beda itu.

\section{Citra Merek}

Merek adalah suatu nama, simbol, tanda, atau desain atau kombinasi diantaranya, dan ditujukan untuk mengidentifikasi barang atau jasa dari seorang penjual atau kelompok penjual dan untuk membedakannya dari para pesaingnya (Kotler; 2003). Kotler (2000), menyebutkan bahwa para pembeli mungkin mempunyai tanggapan berbeda terhadap citra perusahaan atau merek. Citra merek adalah persepsi masyarakat terhadap perusahaan atau produknya. Citra dipengaruhi oleh banyak faktor yang di luar kontrol perusahaan. Citra yang efektif akan berpengaruh terhadap tiga hal yaitu : pertama, memantapkan karakter produk dan usulan nilai. Kedua menyampaikan karakter itu dengan cara yang berbeda sehingga tidak dikacaukan dengan karakter pesaing. Ketiga, memberikan kekuatan emosional yang lebih dari sekadar citra mental.

\section{Kredibilitas Perusahaan}

Kredibilitas Perusahaan adalah tanggung jawab perusahaan terhadap publik-publiknya dan tingkat kepercayaan masyarakat terhadap perusahaan. Kredibilitas perusahaan dapat dibentuk melalui bantuan dari media massa, dimana nantinya informasi dari perusahan dapat tersampaikan kepada konsumen. Menurut Lafferty et al (2002), kredibilitas perusahaan merupakan bagian dari citra perusahaan yang ditimbulkan dari kesan baik yang berasal dari pikiran konsumen. Niat membeli (purchase intention) dipengaruhi secara langsung dan tidak langsung oleh kredibilitas perusahaan (corporate credibility). Pengaruh tidak langsung kredibilitas perusahaan terhadap niat pembelian tersebut adalah melalui sikap terhadap iklan (attitude toward the ad), sikap terhadap merek/produk (attitude toward the brand). Kredibilitas perusahaan (corporate credibility) adalah tingkat sejauhmana konsumen yakin terhadap keterpercayaan dan keahlian perusahaan dalam merancang dan menyediakan atau memberikan produk yang dapat memuaskan kebutuhan dan keinginan pelanggan (Goldsmith et al., 2000).

Niat untuk membeli (intention to buy) Niat atau intensi didefinisikan

sebagai keinginan untuk melakukan perilaku (Jogiyanto, 2007: 29). Niat 
seseorang untuk melakukan perilaku tertentu ditentukan oleh banyak faktor. Menurut theory of reasoned action yang dikembangkan oleh Ajzen dan Fishbein (1980) dalam Jogiyanto (2007: 31), salah satu faktor atau variabel yang mempengaruhi niat adalah sikap. Asumsi yang mendasari teori tersebut adalah, manusia berperilaku dengan cara yang sadar bahwa mereka mempertimbangkan informasi yang tersedia, dan secara implisit dan eksplisit juga mempertimbangkan implikasi-implikasi dari tindakan-tindakan yang dilakukan.

Niat beli diperoleh dari suatu proses belajar dan proses pemikiran yang membentuk suatu persepsi. Niat yang muncul dalam melakukan pembelian menciptakan suatu motivasi yang terus terekam dalam benaknya dan menjadi suatu kegiatan yang sangat kuat yang pada akhirnya ketika seorang konsumen harus memenuhi kebutuhannya akan mengaktualisasikan apa yang ada didalam benaknya itu. Niat untuk membeli merupakan keputusan yang diambil oleh konsumen untuk mendapatkan suatu produk yang dianggap telah sesuai dengan yang diinginkan. Sebelum melakukan suatu pembelian, biasanya konsumen akan mencari informasiinformasi tentang produk yang akan dibeli.

\section{PENELITIAN TERDAHULU}

Penelitian yang dilakukan oleh Dodds et al (1991) telah mencoba untuk menjelaskan pengaruh harga, citra merek, dan nama toko terhadap niat beli konsumen. Rao dan Monroe (1989b) dalam Dodds et al (1991) menyatakan variabel harga dan merek memiliki pengaruh yang signifikan dan positif terhadap niat membeli, sedangkan nama toko tidak memiliki pengaruh yang signifikan terhadap niat membeli. Rao dan Monroe juga menjelaskan sampai saat ini belum ada penelitian mengenai keterkaitan nilai (value) dengan nama toko yang dipublikasikan. Dodds et al (1991) menjalankan penelitian dengan menguji hubungan di antara ketiga variable yang ada. Dalam penelitian ini, pengumpulan data dilakukan dengan kuesioner dan jumlah responden sebanyak 585 orang dijadikan sebagai sumber data penelitian dan di olah. Hasil penelitian terdahulu ini menunjukkan adanya pengaruh signifikan dan postitif harga terhadap niat membeli konsumen.

Penelitian yang dilakukan oleh Rahma (2007) bertujuan untuk mengetahui pengaruh citra merek terhadap niat pembelian. Dalam penelitian ini, pengumpulan data dilakukan dengan kuesioner dan jumlah responden sebanyak 100 orang dijadikan sebagai sumber data dan diolah. Hasil penelitian terdahulu ini menunjukkan adanya pengaruh signifikan dan positif citra merek terhadap niat membeli konsumen.

Penelitian yang dilakukan oleh Lafferty dan Goldsmith (2002) bertujuan untuk memgetahui pengaruh kredibilitas perusahaan terhadap niat pembelian. Dalam penelitian ini, pengumpulan data dilakukan dengan kuesioner dan jumlah responden sebanyak 315 orang dijadikan sebagai sumber data dan diolah. Hasil peneltian terdahulu ini menunjukkan adanya pengaruh signifikan dan positif kredibilitas perusahaan terhadap niat beli konsumen. 


\section{KERANGKA PEMIKIRAN}

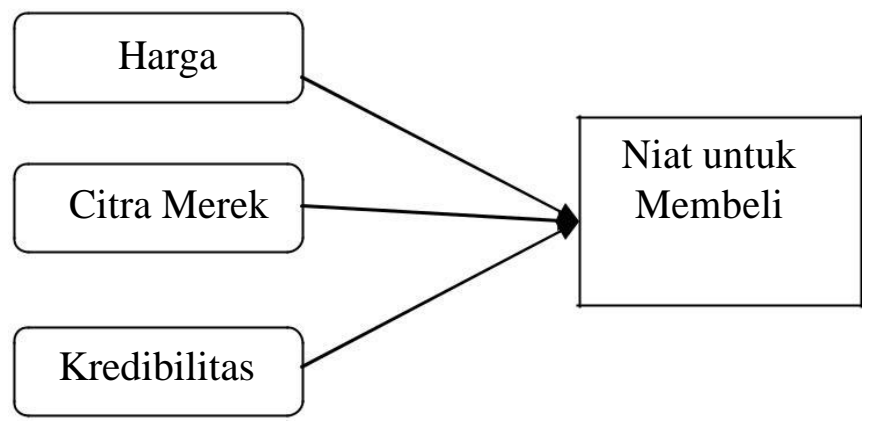

Gambar 1. Kerangka Pemikiran

Sumber : Hasil Olahan Peneliti

\section{HIPOTESIS}

Ha1: Ada pengaruh harga terhadap niat membeli konsumen.

$\mathrm{Ha} 2$ : Ada pengaruh citra merek terhadap niat membeli konsumen

Ha3 : Ada pengaruh kredibilitas perusahaan terhadap niat membeli konsumen.

\section{METODE PENELITIAN}

\section{Tempat dan Waktu}

Peneltian

Penelitian dilakukan di Wilayah Daerah Istimewa Yogyakarta. Waktu pelaksanaan penelitian selama bulan Juli - Agustus 2010.

\section{Teknik Analisis Data}

Analisis data yang dilakukan dalam penelitian ini adalah analisis deskriptif dan analisis kuantitatif. Hasil perhitungan yang dilakukan peneliti dapat diuraikan sebagai berikut:

1. Analisis Statistik

a) Analisis Regresi Berganda.

Bentuk umum persamaan regresi
Berganda dinyatakan dalam persamaan linier sebagai berikut:

(Dajan, 1984:314)

$\mathrm{Y}=\mathrm{a}+\mathrm{b} 1 \mathrm{X}_{1}+\mathrm{b} 2 \mathrm{X}_{2}+\mathrm{b} 3 \mathrm{X}_{3}$

Dimana:

$\mathrm{Y}=$ Niat membeli

konsumen $\mathrm{a}=$ konstanta

$\mathrm{b} 1=$ koefisian regresi untuk

variable bebas $\mathrm{X}_{1}$

$\mathrm{b} 2=$ koefisien regresi untuk

variable bebas $\mathrm{X}_{2}$

b3= koefisien regresi untuk

variable bebas $\mathrm{X}_{3}$

$\mathrm{X}_{1}=$ variabel Harga

$\mathrm{X}_{2}=$ variable Citra Merek

$\mathrm{X}_{3}=$ variabel Kredibilitas

Perusahaan

b) Uji - T. Pembuktikan hipotesis kedua digunakan uji $\mathrm{T}$ untuk mengetahui pengaruh dari masingmasing variabel bebas terhadap variable terikat dengan menggunakan program SPSS.

c) Uji - F. Digunakan untuk menunjukkan apakah semua variabel bebas yang dimasukkandalam model mempunyai pengaruh secara bersama-sama terhadap variabel independen dengan menggunakan program SPSS

2. Uji Asumsi Klasik

a) Bebas multikolinieritas

Bertujuan untuk menguji apakah model regresi ditemukan adanya korelasi antar variabel bebas. Model regresi yang baik seharusnya tidak terjadi korelasi diantara variabel independen. Jika variabel independen saling berkorelasi, maka variabel- 
variabel ini tidak ortogonal. Variabel ortogonal adalah variabel independen yang nilai korelasi antar sesama variabel independen sama dengan nol (Ghozali, 2001).

b) Uji Normalitas

Bertujuan untuk menguji apakah dalam model regresi, variabel pengganggu atau residual memiliki distribusi normal. Metode yang lebih handal adalah dengan melihat normal probability plot yang mambandingkan distribusi kumulatif dari distribusi normal. Distribusi normal akan membentuk satu garis lurus diagonal, dan ploting data residual akan dibandingkan dengan garis diagonal. Jika berdistribusi data residual normal, maka garis yang menggambarkan data sesungguhnya akan mengikuti garis diagonalnya (Ghozali, 2001).

c) Uji Linieritas

Secara implisit teknik multivarian berdasarkan pada ukuran korelasi. Korelasi hanya diwakili oleh hubungan linier antara variabel-variabelnya. Oleh karena itu, dampak non linier tidak dapat mewakili

dalam hubungan ini. Untuk

menghindari hal itu, dalam pengujian awal dilakukan estimasi linieritas dengan perangkat yang telah disediakan dalam program SPSS.

3. Uji Koefisien Determinasi Ganda $\left(\mathrm{R}^{2}\right)$ Uji koefisien determinasi ganda yaitu untuk mengetahui besarnya pengaruh semua pengaruh variabel bebas
(X) seraca serempak terhadap variabel terikat (Y). Dengan pengolahan data melalui SPSS, $\mathrm{R}^{2}$ adalah angka yang menunjukkan berapa \% (proporsi) variabel terikat yang dipengaruhi oleh variabelvariabel bebas, atau dari $100 \%$ variabel-variabel yang berpengaruh terhadap variabel terikat, sekian \% dipengaruhi oleh variabel bebas, sedangkan sisanya dipengaruhi oleh variabel lain yang tidak diketahui karena tidak dimasukkan dalam data. Semakin besar nilai $\mathrm{R}^{2}$, maka semakin baik model tersebut (Ghozali, 2005).

\section{HASIL DAN \\ PEMBAHASAN Uji Multikolinieritas}

Bertujuan untuk menguji apakah model regresi ditemukan adanya korelasi antar variabel bebas. Model regresi yang baik seharusnya tidak terjadi korelasi diantara variabel independen. Kriteria pengujiannya adalah jika nilai VIF > 10 atau nilai Tolerance $<0,10$ maka Ho.ditolak, yang berarti terjadi multikolinieritas. Begitupun sebaliknya jika nilai VIF < 10 atau nilai Tolerance > 0,10 maka Ho diterima, yang berarti tidak terjadi multikolonieritas. Dengan menggunakan software pengolah data SPSS ver. 16, maka diperoleh hasil perhitungan sebagai berikut :

Tabel 2

Hasil Uji Multikolinieritas

\begin{tabular}{|l|c|c|}
\hline \multirow{2}{*}{ Dimensi } & \multicolumn{2}{|c|}{$\begin{array}{c}\text { Colliniearity } \\
\text { Statistics }\end{array}$} \\
\cline { 2 - 3 } & Tolerance & VIF \\
\hline Harga & 0.485 & 2.061 \\
Citra_merek & 0.516 & 1.939 \\
Kredibilitas_perusahaan & 0.780 & 1.281 \\
& & \\
\hline
\end{tabular}

Sumber : Data primer diolah, 2010 
Dari hasil uji multikolonieritas, yang ditunjukkan pada Tabel 2 menunjukkan bahwa :

a. Pengujian multikolinieritas pada variable Harga $\left(\mathrm{X}_{1}\right)$ :

Berdasarkan hasil uji multikolinieritas untuk variable harga, maka Ho diterima dan Ha ditolak. Hal ini dikarenakan variable ini memiliki nilai VIF sebesar 2,061 dan nilai tolerance 0,485, berarti Ho diterima. Sehingga variable harga $\left(\mathrm{X}_{1}\right)$ tidak terjadi multikolinieritas.

b. Pengujian multikolinieritas pada variable citra merek

$\left(\mathrm{X}_{2}\right)$ :

Berdasarkan hasil uji multikolinieritas untuk variabel citra merek, maka Ho diterima dan $\mathrm{Ha}$ ditolak. Hal ini dikarenakan variabel ini memiliki nilai VIF sebesar 1,939 dan nilai tolerance sebesar 0,516, berarti Ho diterima. Sehingga variabel citra merek $\left(\mathrm{X}_{2}\right)$ tidak terjadi multikolinieritas.

c. Pengujian multikolinieritas pada variable kredibilitas perusahaan $\left(\mathrm{X}_{3}\right)$ :

Berdasarkan hasil uji multikolinieritas untuk variabel kredibilitas perusahaan, maka Ho diterima dan $\mathrm{Ha}$ ditolak. Hal ini dikarenakan variabel ini memiliki nilai VIF sebesar 1,281 dan nilai tolerance sebesar 0,780, berarti Ho diterima. Sehingga variabel kredibilitas perusahaan $\left(\mathrm{X}_{3}\right)$ tidak terjadi multikolinieritas.

\section{Uji Normalitas}

Bertujuan untuk menguji apakah dalam model regresi, variabel pengganggu atau residual memiliki distribusi normal. Metode yang lebih handal adalah dengan melihat

normal probability plot yang mambandingkan distribusi kumulatif dari distribusi normal. Untuk membuktikan hal tersebut maka dilakukan pengolahan data dengan software SPSS ver. 16 dan hasilnya dapat dilihat pada gambar dibawah ini:

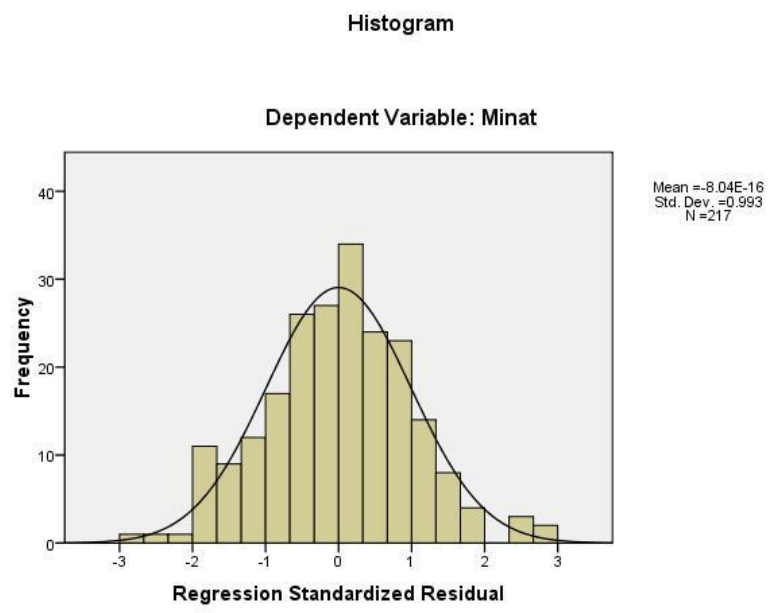

\section{Gambar 2 \\ Uji Normalitas}

Sumber : Data primer diolah, 2010

Hasil uji normalitas berupa diagram pada Gambar 2 dapat menunjukkan model

regresi. Dalam grafik histogram menunjukkan adanya pola distribusi normal, maka model regresi memenuhi asumsi normalitas.

\section{Uji Linieritas}

Uji linieritas bertujuan untuk mengetahui apakah hubungan variabel bebas terhadap variabel terikat merupakan 
hubungan linier atau non linier. Untuk membuktikan hal tersebut maka dilakukan pengolahan data dengan software SPSS ver. 16 dan hasilnya dapat dilihat pada gambar dibawah ini:

Sumber : Data primer diolah, 2010 Gambar 3 Uji Linieritas

Dari Gambar 3 diatas dapat dilihat hasil uji linieritas menunjukan titik menyebar disekitar garis diagonal dan mengikuti arah garis diagonal, maka model regresi memenuhi asumsi linieritas.

\section{Koefisien Determinasi}

Koefisien determinasi $\mathrm{R}$ square $\left(\mathrm{R}^{2}\right)$, yang merupakan alat analisa untuk menunjukkan besarnya persentase pengaruh variabel bebas (X) secara keseluruhan terhadap niat membeli (Y). Berdasakan tabel 4.13 diperoleh koefisien determinasi $\left(\mathrm{R}^{2}\right)$ sebesar 0,449 yang berarti $44,9 \%$ dari niat beli dipengaruhi secara bersama-sama oleh variabel bebas. Sedangkan sisanya $55,1 \%$ dipengaruhi oleh faktor lain yang tidak dimasukkan dalam model.

\section{Regresi Linier Berganda}

Analisis regresi linear berganda digunakan untuk membuktikan hipotesis dengan formula sebagai berikut : $\mathrm{Y}=0,413+0,372 \mathrm{X}_{1}+0,346 \mathrm{X}_{2}+0,128 \mathrm{X}_{3}$

Dalam menganalisis regresi linier berganda, penulis menggunakan seri program statistik SPSS versi 16 dan hasilnya dapat ditunjukkan pada Tabel 4.13 berikut :

Tabel 3

Estimasi Regresi Linear Berganda

\begin{tabular}{|c|c|c|c|c|c|}
\hline $\begin{array}{c}\text { Variabel } \\
\text { Independe } \\
\mathbf{n}\end{array}$ & $\begin{array}{c}\text { Koef. } \\
\text { Regr } \\
\text { esi } \\
\text { (B) }\end{array}$ & Sig & $\mathbf{r}$ & $\mathbf{r}^{2}$ & $\begin{array}{c}\text { thitu } \\
\mathbf{n g}\end{array}$ \\
\hline Konstanta & 0.4 & 0.1 & - & & 1.624 \\
Harga $\left(\mathrm{X}_{1}\right)$ & 0.3 & 0.0 & 0.3 & 0.0 & 4.801 \\
\hline
\end{tabular}

\begin{tabular}{l|c|c|c|c|c} 
& 72 & 00 & 12 & 97 & \\
\hline Citra & 0.3 & 0.0 & 0.2 & 0.0 & 4.343 \\
Merek $\left(\mathrm{X}_{2}\right)$ & 46 & 00 & 85 & 81 & \\
\hline Kredibilitas & 0.1 & 0.0 & 0.1 & 0.0 & 2.113 \\
Perusahaan & 28 & 36 & 43 & 20 & \\
$\left(\mathrm{X}_{3}\right)$ & & & & & \\
\hline
\end{tabular}

Variabel dependen: Niat Membeli (Y) $\mathrm{R}^{2}=0.449 ;$ Fhitung $=57.914 ; \mathrm{Sig}=0.000$

Sumber : Data primer diolah, 2010

Dari persamaan regresi pada table 3, maka arti dari masing-masing nilai koefisien regresi adalah sebagai berikut :

1. Harga $(X 1)=0,372$

Artinya apabila variabel harga semakin baik (bertambah satu point) maka niat membeli oleh konsumen pada produk Kawasaki akan bertambah sebesar 0,372

point, dengan asumsi variabel independen lainnya konstan (ceteris paribus).

2. Citra Merek $(X 2)=0,346$

Artinya apabila variabel citra merek semakin baik (bertambah satu point) maka niat membeli oleh konsumen pada produk Kawasaki akan bertambah sebesar 0,346 point, dengan asumsi variabel independen lainnya konstan (ceteris paribus).

3. Kredibilitas Perusahaan $(X 3)=$ 0,128 Artinya apabila variabel kredibilitas

perusahaan semakin baik (bertambah satu point) maka niat membeli oleh konsumen pada produk Kawasaki akan bertambah sebesar 0,128 point, dengan asumsi variabel independen lainnya konstan (ceteris paribus). 
Uji T dimaksudkan untuk membuktikan dari penelitian yang menyatakan masingmasing variabel independen mempunyai pengaruh terhadap variabel terikatnya atau dependen. Berikut ini hasil pengolahan data dengan bantuan program SPSS ver.16 :

Tabel 4 Hasil Uji T

\begin{tabular}{|l|c|c|}
\hline \multicolumn{1}{|c|}{ Dimensi } & Sig. & $\alpha$ \\
\hline Harga & 0.000 & \\
Citra_merek & 0.000 & 0.05 \\
Kredibilitas_perusahaan & 0.036 & \\
\hline
\end{tabular}

Sumber : Data primer diolah, 2008

Table 4 menggambarkan bahwa dari ketiga variabel bebas yang ada, yaitu harga, citra merek, dan kredibilitas perusahaan memiliki probabilitas signifikan dan positif, yaitu sebesar 0,000; 0,000; dan 0,036; jauh lebih kecil dari $\alpha(0,05)$ yang artinya Ho ditolak dan $\mathrm{Ha}$ diterima. Ini menandakan variabel harga, citra merek, dan kredibilitas perusahaan memiliki pengaruh secara sendiri atau parsial terhadap niat konsumen membeli produk Kawasaki di Yogyakarta.

\section{Uji - F}

Untuk mengetahui signifikansi pengaruh semua variabel independen secara bersama-sama terhadap variabel dependen digunakan Uji F. Analisis dari hasil uji $\mathrm{F}$ (uji serentak) dimaksudkan untuk membuktikan dari penelitian yang menyatakan bahwa variabel-variabel yang terdiri dari harga, citra merek, dan kredibilitas perusahaan berpengaruh terhadap niat membeli konsumen. Berikut ini hasil pengolahan data dengan bantuan program SPSS ver.16;
Tabel 5 Hasil Uji F

\begin{tabular}{|l|r|r|r|c|c|}
\hline \multicolumn{1}{|c|}{ ANOVA $^{\text {S }}$} \\
\hline Model & $\begin{array}{r}\text { Sum of } \\
\text { Squares }\end{array}$ & df & $\begin{array}{r}\text { Mean } \\
\text { Square }\end{array}$ & F & Sig. \\
\hline 1 Regression & 50.266 & 3 & 16.755 & 57.914 & $.000^{\mathrm{a}}$ \\
Residual & 61.624 & 213 & .289 & & \\
Total & 111.890 & 216 & & & \\
\hline
\end{tabular}

Sumber : Data primer diolah, 2010

Dari Tabel 5 dapat dilihat hasil uji F, diperoleh F $_{\text {hitung sebesar 57,914 }}$ dan signifikan sebesar $0,000<0,05$ maka Ho

ditolak dan Ha diterima, atau dapat disimpulkan bahwa terdapat pengaruh secara bersama variabel yang terdiri dari harga, citra merek, dan kredibilitas perusahaan terhadap niat membeli konsumen.

\section{PENUTUP}

Berdasarkan dari hasil penelitian ini diperoleh beberapa kesimpulan yang secara ringkas disajikan sebagai berikut :

1. Berdasarkan hasil uji regresi secara bersama-sama (Uji F), didapatkan nilai signifikansi probabilitasnya sebesar 0,000 , dengan level of signifikan sebesar 0,05 maka dapat disimpulkan taraf signifikan $0,000 \leq 0,05$, artinya variabel harga, citra merek, dan kredibilitas

perusahaan secara keseluruhan mempunyai pengaruh yang signifikan dan positif terhadap niat membeli.

2. Berdasarkan hasil uji regresi parsial (Uji T), didapatkan nilai signifikansi untuk harga sebesar 0,000 dengan level of 
signifikan sebesar 0,05, sehingga ada pengaruh harga dengan niat membeli. Hasil uji regresi parsial (uji T) untuk citra merek sebesar 0,000 dengan level of signifikan sebesar 0,05, Sehingga ada pengaruh signifikan dan positif citra merek dengan niat membeli. Hasil uji regresi parsial (uji T) untuk kredibilitas perusahaan sebesar 0,036 dengan level of signifikan sebesar 0,05, sehingga ada

pengaruh signifikan dan positif kredibilitas perusahaan dengan niat membeli.

Berdasarkan hasil penelitian yang telah terurai sebelumnya, maka dapat diberikan saran yaitu sebagai berikut:

\section{Bagi Perusahaan}

1. Kawasaki dapat menggunakan kebijakan berupa diskon atau potongan harga untuk menarik niat membeli konsumen terhadap produknya. Dengan kebijaksanaan harga yang tepat, hal ini bukan saja mendatangkan tingkat permintaan yang tinggi, melainkan juga akan membuat perusahaan mampu bersaing dengan perusahaan-perusahaan sejenis.

2. Kawasaki harus dapat memproduksi motor dengan berbagai macam karakteristik model yang menarik agar tidak mudah ditiru oleh para pesaingnya dan menciptakan kepuasan pada diri konsumen yang membelinya. Hal ini juga bertujuan agar konsumen dapat memilih model motor Kawasaki yang sesuai dengan keinginan.
3. Kawasaki meningkatkan kegiatan promosi dengan mengguanakan bantuan media massa, agar informasi mengenai produk Kawasaki tersampaikan ke konsumen. Model iklan (endoser) dapat juga digunakan dalam kegiatan promosi agar dapat menarik perhatian serta niat membeli konsumen.

\section{Bagi Peneliti Selanjutnya}

1. Masih dimungkinkannya bagi penelitian selanjutnya untuk memakai variabel-variabel lain sebagai variabel bebas untuk penelitian tentang niat membeli terhadap motor Kawasaki, karena masih terdapat $55,1 \%$ yang tidak dapat dijelaskan oleh variable bebas dalam penelitian ini.

2. Hasil penelitian ini tidak dapat digeneralisasi karena wilayah penelitian yang terbatas, yaitu Daerah Istimewa

Yogyakarta. Diharapkan dalam penelitian selanjutnya dapat diperluas lagi area penyebaran kuesioner, baik dengan cara langsung maupun menggunakan media elektronik seperti internet.

3. Diharapkan bagi penelitian selanjutnya tidak hanya menggunakan niat membeli sebagai variabel terikatnya, tetapi dapat menambahkan variabel lain seperti keputusan pembelian dan loyalitas konsumen, sehingga akan terlihat sejauh mana keinginan konsumen akan suatu produk. 


\section{DAFTAR PUSTAKA}

Aaker David A. (1996).Building Strong Brands 1 st ed., The Free Press: New York.

Ardianto, Eka. (1999). "Mengelola Aktiva Merek: Sebuah

Pendekatan Strategis"; Forum Manajemen Prasetiya Mulya, No. 67, p.34-39.

Bellenger, Danny N. and Moschis, George P. (1982). "A Socialization Model of Retail Patronage." Advances in Consumer Research, 9:373-378.

Dobni, D. and Zinkhan, G.M. (1990), "In search of citra merek: a foundation analysis", in Goldberg, M.E., Gorn, G. and Pollay, R.W. (Eds), Advances in Consumer Research, Association for Consumer Research, Provo, UT, pp. 110-19

Dodd, Willian B, Kent B. Monroe \& Dhruv Grewal.(1991). "Effect of price, brand and store information on buyer'sproduct evaluation". Jurnal of Marketing research, 28:307-319.

Ghozali, Imam. (2005). Aplikasi Analisis Multivariate dengan Program SPSS edisi Keempat. Penerbit Universitas Diponegoro.

Grewal, D., Krishnan, R., Baker, J., Borin, N. (1998). "The effect of store name, brand name and price discounts on consumers' evaluations and purchase intentions", Journal of Retailing, 74:331-352.

Istijanto, (2005). "Aplikasi Praktis Riset Pemasaran, Plus tiga puluh enam topic Riset Pemasaran".Jakarta Gramedia Pustaka Utama.
Lamb, Charles W., Joseph F.Hair, Carl McDaniel. (2001). Pemasaran. Jakarta : Penerbit Salemba Empat.

Lafferty, B. A, Goldmith, R. E. and Newel, S. J. (2002). "The Dual Credibility Model: The Influence of Corporate and Endorser Credibility on Attitudes and Purchase Intentions". Journal of Marketing, 1-11.

Nugroho, J, Setiadi. (2003). "Perilaku Konsumen, konsep dan implikasi untuk strategi dan penelitian pemasaran". Jakarta : Prenada Media

Rahma, Eva Sheilla. (2007). “Analisis pengaruh kualitas layanan dan citra merek terhadap minat beli dan dampaknya pada keputusan pembelian (Studi Pada Pengguna Telepon Seluler Merek Sony Ericson di Kota

Semarang).Thesis program

Magister Manajemen

Universitas Diponegoro (tidak dipublikasikan)

Rao, Akshay R. and Kent B. Monroe. (1988). "The Effect of Price, Brand Name, and Store Name on Buyers' Perceptions of Product Quality: An Integrative Review," Journal of Marketing Research. 351-7.

Swani, Kunal and Boonghee Yoo. (2009). "Interaction between price and price deal". Journal of product and brand management, - 152 .

Umar, Husein. (2003). Riset Pemasaran dan Perilaku Konsumen. Jakarta : Penerbit Gramedia Pustaka Utama. 